\title{
Mineral Bioavailability, Physico-Chemical and Sensory Properties of Granola Produced from Different Cereals and Processing Methods
}

\author{
Eke-Ejiofor J*, Beleya E.A, Onyekwe J. C \\ Department of Food Science and Technology, Rivers State University, Nkpolu Oroworukwo P.M.B.5080, Port Harcourt \\ *Corresponding author: joyekee@yahoo.co.uk
}

\begin{abstract}
Twelve breakfast cereals were formulated. Eight of them were baked with four samples having sugar and four with date fruit as sugar replacer, while the last four extruded. Yellow maize granola with sugar was used as control. The samples were subjected to sensory, chemical and functional analysis as well as mineral bioavailability. Sensory analysis showed a significant difference $(\mathrm{p} \leq 0.05)$ in color, taste, flavor, texture and overall acceptability for baked product while for extruded samples; there was a significant difference in color, taste and flavor with no significant difference $(\mathrm{p} \geq 0.05)$ in texture and overall acceptability. Samples produced with date showed an increase in the ash, fat, protein and energy contents with a decrease in moisture content except the maize products which showed a decrease in their fat contents. The result also showed that the extrusion process increased crude fiber, carbohydrate and starch with very low fat and moisture content, with a reverse in the sugar baked granola. Functional analysis of the samples showed an increase in swelling power and water absorption capacity with the date baked granola, but not statistically different $(\mathrm{p} \geq 0.05)$. Mineral analysis using Atomic Absorption Spectrophotometer (AAS) investigated calcium, sodium, iron, magnesium and potassium as well as bioavailability of minerals studied using Pepsin and Pancreatin enzymes in an in-vitro digestion method. The products were high in calcium, sodium and potassium and very low in iron. However not all the minerals detected were bioavailable. A mineral range of $87.36-91.29 \%$ and $87.04-88.13 \%$ of sodium and potassium were available in soluble forms in sugar baked granola, while $69.93-73.38 \%$ and $87.04-88.13 \%$ of sodium and potassium in date containing products and a decrease of $46.85-70.50 \%$ and $73.02-90.25 \%$ for sodium and potassium in extruded products. This study showed that the production of granola from locally available cereals and inclusion of date fruit gave a desirable product with improved nutritional values.
\end{abstract}

Keywords: granola, cereals, processing method, physico-chemical, mineral bioavailability, sensory

Cite This Article: Eke-Ejiofor J, Beleya E.A, and Onyekwe J. C, "Mineral Bioavailability, Physico-Chemical and Sensory Properties of Granola Produced from Different Cereals and Processing Methods." American Journal of Food Science and Technology, vol. 5, no. 6 (2017): 256-264. doi: 10.12691/ajfst-5-6-6.

\section{Introduction}

The perception of food has changed tremendously as a result of technological advancement and increased nutritional awareness. There is a demand for convenient and ready to eat foods by most consumers which add bulk and satiety to their appetite [1]. The need for food has transcended to foods enriched with dietary fibre and micronutrients which aid in some physiological reductions such as cholesterol, blood sugar level and improved colonic health [2].

Breakfast cereals are ready to eat foods made from cereal grains like rice, wheat, maize and Oat [1]. Granola a breakfast cereal, is basically known to be made from oats, walnut, peanut and wheat [3] but other locally available materials such as maize, millet and guinea corn have been used in its production and has shown to be rich in carbohydrates, dietary fibre, low fat, protein and varying amounts of minerals such as calcium, magnesium, potassium and iron $[2,3]$.
There is an increased consumer awareness towards less sugar consumption or sugar free foods and as a result some natural alternatives have been made available as sugar replacers in foods namely; raw honey, brown rice syrup, corn syrup, molasses, date palm [4,5].

Date fruit locally known as "Debino" in Hausa language of Nigeria, has been used to replace sugar in so many food products like bread, cake and cookies $[5,6]$. The wide use of dates in food may be attributed to its richness in carbohydrates in form of sugars, dietary fibre, proteins, vitamins mainly $A, B_{1}$ and $B_{2, \text {, abundant minerals }}$ like iron, potassium, calcium, chlorine, magnesium [5] as well as its low glycemic index that reduces carbohydrates digestion and absorption, remedies for hangovers and alcoholic intoxication as well as its benefits during pregnancy and childbirth $[7,8]$.

Granola an unpopular breakfast cereal has been found to contain some minerals namely: calcium, potassium, sodium, magnesium, iron, zinc copper and phosphorus [9]. Its production has seen many declines in consumption over the years but gained popularity since the invention of 
granola bar due to its increased health benefit, convenience, delicious taste and versatility in various meals [10]. Bioavailability of mineral can be seen as the proportion of mineral intake capable of being absorbed through the intestine and made available either for metabolic use or storage [11]. The mineral bioavailability of some foods has been evaluated using the In-vitro digestibility method developed by Elles et al., [12], Kiin-Kabari et al. [13].

Processing methods has shown to have an effect on the bioavailability of nutrients in food. The use of high temperature short time extrusion cooking has been used in the production of breakfast cereals and snack foods [1,14] and as such was used in this study in the production of granola and compared with conventional baking method. There is little or no information on the effect of date inclusion, processing and bioavailability of minerals in granola or related products; therefore, the objectives of this work are.

To prepare and evaluate the effect of date meal inclusion as a sugar replacer and processing methods on the chemical and sensory properties of granola

To determine the percentage soluble fraction (bioavailability) of minerals present in granola

\section{Materials and Methods}

\subsection{Materials}

Maize (Zea may), Millet (Peniselum glaucum), Guinea corn (Sorghum bicolor), Peanut (Arachis hypogaea), Coconut (Cocus nucifera), Wheat (Triticum spp), Dates (Phoenix dactylifera), Milk, Sugar, Vegetable oil and Vanilla flavor were purchased from Mile 3 Market in Port Harcourt, Rivers State Nigeria.

\subsection{Chemicals}

All chemicals used for this work were of analytical grade and obtained from the Department of Food Science and Technology Laboratories, Rivers State University, Port Harcourt

\subsection{Methods}

\subsubsection{Preparation of Cereal Whole Meals}

Cereal grains such as Maize (yellow and white), Guinea corn and Millet were sorted to remove impurities, cleaned, winnowed and the grains milled using a dry milling machine (M6FFC Grain mill). The meals obtained were then stored in an air-tight container for use in granola production.

\subsubsection{Preparation of Date Pulp}

The seeds of the date palm fruits were removed and discarded. The pericarp were oven dried at $45^{\circ} \mathrm{C}$ for $8 \mathrm{hrs}$ and milled using hand milling (M6FFC grain mill) machine [5].

\subsection{Composition and Production of Granola}

Granola, a cereal based meal were made from $500 \mathrm{~g}$ each of maize, millet, guinea corn, respectively with coconut $(80 \mathrm{~g})$, peanut $(160 \mathrm{~g})$, wheat flour $(100 \mathrm{~g})$, sugar/date $(160 \mathrm{~g})$, water $(200 \mathrm{ml})$, vegetable oil $(16 \mathrm{ml})$ and vanilla flavor $(4 \mathrm{ml})$ mixed into dough. Part of the dough was rolled, spread on the tray and baked at $130^{\circ} \mathrm{C}$ for 50 minutes [9], while the other part was subjected to extrusion cooking [15]. The baked and extruded products (granola) were allowed to cool and stored in an airtight container.

\subsection{Enzyme Preparation for In-vitro Digestibility}

Pepsin Enzyme Solution: $16 \mathrm{mg}$ of pepsin, $3.5 \mathrm{ml}$ of $0.06 \mathrm{~N} \mathrm{HCl}$ and $1.0 \mathrm{~g}$ Sodium Chloride was mixed and made up to $100 \mathrm{ml}$ with deionized water.

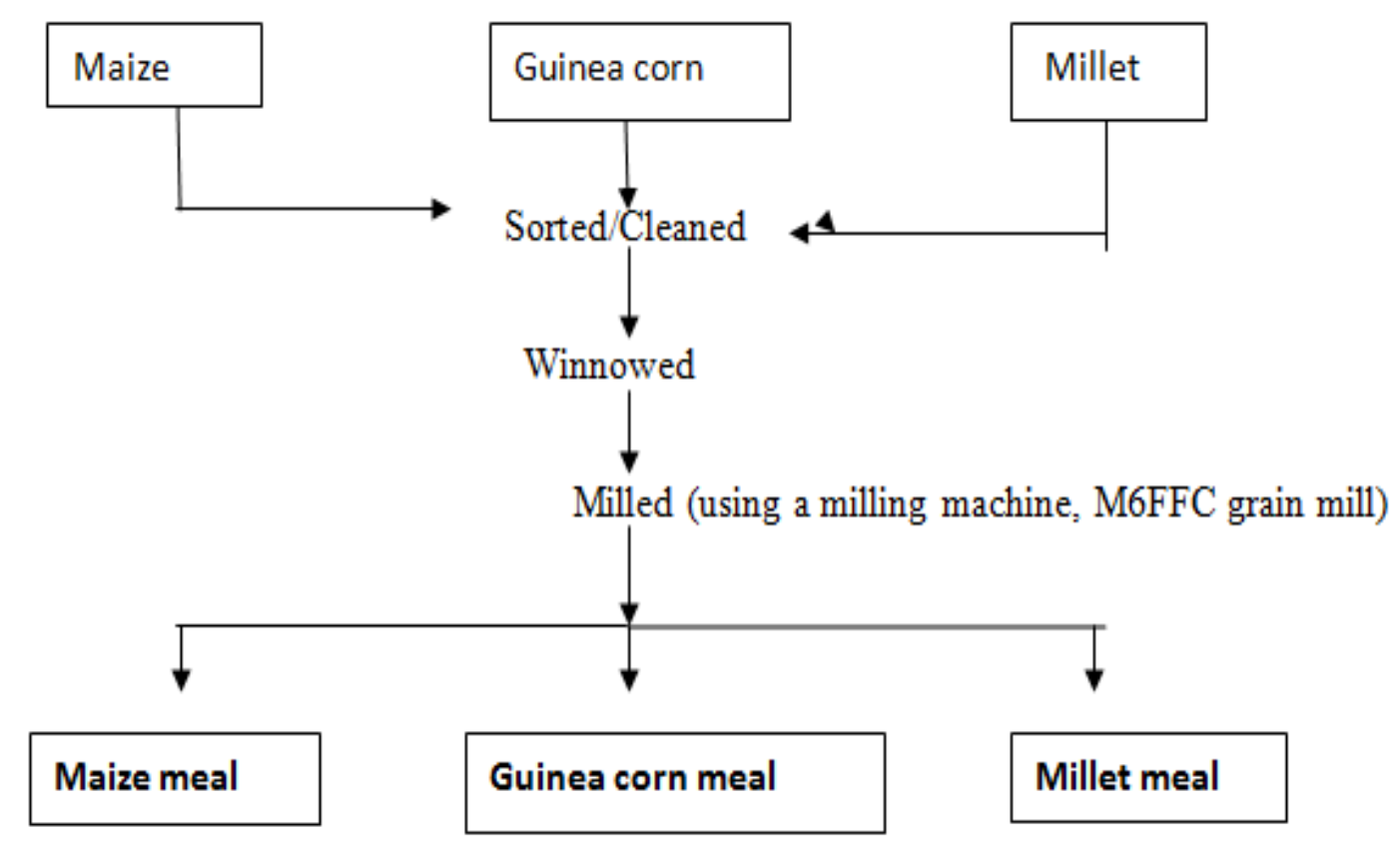

Figure 1. Flowchart for the production of cereal meals (Source: [9]) 
Pancreatin Enzyme Solution: $1.6 \mathrm{~g}$ of pancreatin was dissolved in phosphate buffer $\left(\mathrm{P}^{\mathrm{H}} 7.5\right)$ and made up to $100 \mathrm{ml}$ with same buffer solution.

\subsection{Sensory Evaluation of Granola}

The baked and extruded granola samples were subjected to sensory evaluation. The granola samples were evaluated in milk solution, the form in which it would be consumed and the following parameters assessed for color/appearance, taste, aroma, crispness, texture and overall acceptability, using a 5 point hedonic scale [16]. A total of twenty (20) semi trained panelists drawn from Food Science and technology department who were neither sick nor allergic to any of the raw materials used in the production, were instructed to rinse their mouth with water after tasting each sample.

\subsection{Statistical Analysis}

Results were statistically analyzed by using analysis of variance technique. Level of significance within means was calculated using the Least Significant Difference and Standard deviation methods.

\subsection{Chemical Analysis of Granola Samples}

The moisture content of the granola samples was determined using the moisture analyzer (DBS 60-3) at $130^{\circ} \mathrm{C}$, while the method described by AOAC [17] was used to determine ash, protein, fat and fibre with carbohydrate calculated by difference. The total energy values of the different samples were determined using the method of Mahgoub [18]. Starch and Sugar was determined by the method of Prapasri et al. [19].

\subsection{Functional Analysis}

Relative bulk density was determined by the method of Narayana and Narasinya [20] while dispersibility was determined by the method of Kulkarni et al., [21]. Swelling power and solubility was determined using the method of Takashi and Sieb [22], while water absorption capacity was determined by the method of Sosulski [23].

\subsection{Mineral Analysis}

\subsubsection{Total Mineral}

This was done by dry ash method according to AOAC [17] and mineral bioavailability determined using the invitro enzyme digestion method as described by Ikeda [24].

\section{Results and Discussion}

\subsection{Sensory Evaluation Result of Baked Granola Sample}

Table 1 shows the sensory evaluation result of eight baked granola samples produced from two sets of four cereals namely maize( yellow and white), Guinea corn and millet; one set produced with sugar and the other produced with date fruit, all consumed in a given quantity of milk and sugar in the ratio 4:1,weight for weight. Color/Appearance ranged from $2.85-6.25$ with sample A (yellow maize/sugar) as the highest and sample $\mathrm{H}$ (millet/date) as the least. Result of sensory evaluation of baked granola showed that there was significant difference $(\mathrm{p} \leq 0.05)$ in color between the maize based granola produced with sugar and the non sugar containing samples.

Taste ranged from $2.50-4.50$ with sample $\mathrm{F}$ (white maize/date) as the highest and sample $\mathrm{H}$ (millet/date) as the least. Flavor ranged from $2.70-4.30$ with sample E (yellow maize/date) as the highest and sample $\mathrm{H}$ (millet/date) as the least. Texture ranged from $2.45-4.30$ with sample $F$ (white maize/date) as the highest and sample $\mathrm{H}$ (millet/date) as the least. Overall acceptability ranged from $2.70-4.45$ with samples $E$ and $F$ (yellow and white maize/date) as the highest and sample $\mathrm{H}$ (millet/date) as the least.

Taste, Flavor, Texture and Overall acceptability showed significant difference $(p \leq 0.05)$ with sample $E$ (yellow maize + date) been the most preferred in taste, flavor and overall acceptability. There was a significant difference $(\mathrm{p} \leq 0.05)$ in texture between sugar baked products, date baked and extruded samples.

The use of date as sugar replacer showed a decrease in color and texture when compared with the sugar containing samples. This may be due to the brown color, fiber and fat content in the raw date.

Table 1. Sensory Evaluation Result of Baked Granola Samples

\begin{tabular}{cccccc}
\hline Sample & Color & Taste & Flavor & Texture & $\begin{array}{c}\text { Overall } \\
\text { acceptability }\end{array}$ \\
\hline A & $6.25^{\mathrm{a}}$ & $3.80^{\mathrm{a}}$ & $3.90^{\mathrm{a}}$ & $5.70^{\mathrm{a}}$ & $3.85^{\mathrm{a}}$ \\
B & $6.20^{\mathrm{a}}$ & $3.65^{\mathrm{a}}$ & $3.60^{\mathrm{a}}$ & $5.65^{\mathrm{a}}$ & $3.60 \mathrm{a}$ \\
C & $6.10^{\mathrm{b}}$ & $4.00^{\mathrm{a}}$ & $3.85^{\mathrm{a}}$ & $5.80^{\mathrm{a}}$ & $3.90 \mathrm{a}$ \\
D & $5.75^{\mathrm{c}}$ & $3.35^{\mathrm{b}}$ & $3.35^{\mathrm{b}}$ & $5.50^{\mathrm{a}}$ & $3.35^{\mathrm{b}}$ \\
E & $4.00^{\mathrm{d}}$ & $3.80^{\mathrm{a}}$ & $4.30^{\mathrm{a}}$ & $4.05^{\mathrm{b}}$ & $4.45^{\mathrm{a}}$ \\
F & $4.45^{\mathrm{d}}$ & $4.50^{\mathrm{a}}$ & $3.80^{\mathrm{a}}$ & $4.30^{\mathrm{b}}$ & $4.45^{\mathrm{a}}$ \\
G & $3.15^{\mathrm{e}}$ & $3.00^{\mathrm{b}}$ & $2.85^{\mathrm{b}}$ & $2.85^{\mathrm{c}}$ & $3.05^{\mathrm{b}}$ \\
H & $2.85^{\mathrm{f}}$ & $2.50^{\mathrm{c}}$ & $2.70^{\mathrm{b}}$ & $2.45^{\mathrm{c}}$ & $2.70^{\mathrm{c}}$ \\
\hline
\end{tabular}

Means with the same superscript in the same column are not significantly different $(\mathrm{P} \geq 0.05)$.

Key: $A=$ Yellow maize / sugar

$\mathrm{B}=$ White maize / sugar

$\mathrm{C}=$ Guinea corn / sugar

$\mathrm{D}=$ Millet $/$ sugar

$\mathrm{E}=$ Yellow maize $/$ date

$\mathrm{F}=$ White maize / date

$\mathrm{G}=$ Guinea corn $/$ date

$\mathrm{H}=$ Millet $/$ date.

\subsection{Sensory Evaluation Result of Extruded Granola Samples}

Table 2 shows the sensory evaluation result of extruded granola samples produced from four different cereals namely; maize(yellow and white), guinea corn and millet with either sugar or date fruit consumed in a given quantity of milk and sugar in the ratio of $4: 1$,weight for weight. Color/Appearance ranged from 3.35 - 4.05 with sample K (guinea corn/sugar) as the highest and sample I (yellow maize/date) as the least. Taste range Flavor ranged from $3.00-4.05$ with sample I (yellow maize /date) 
as the highest and sample L (millet /date) as the least. Texture ranged from 3.00- 3.95 with sample I (yellow maize /date) as the highest and sample L (millet/date) as the least. Overall acceptability ranged from 3.00 -4.15 with sample I (yellow maize/date) as the highest and sample L (millet/date) as the least.

From the sensory evaluation of extruded products, result showed that color, taste, flavor, texture and overall acceptability respectively where significantly different from each other except in texture which showed no significant difference between the samples. In Overall acceptability, samples I, J and $\mathrm{K}$ (extruded yellow, white maize and guinea corn) were the most preferred and showed no significant difference $(p \geq 0.05)$. Sample I (yellow maize) showed to have the highest value in overall acceptability but least in color. This may be due to Millard reaction (reaction between protein and sugar) or the effect of high temperature on the carotenoid content of yellow maize [25].

\subsection{Chemical Composition Result of Granola Samples}

Table 3 shows the chemical analysis result of baked and extruded granola samples prepared from four different cereals with either sugar or dates. Moisture content ranged from $2.70-8.45 \%$ with sample $\mathrm{F}$ (white maize /date-baked) as the highest and sample $\mathrm{J}$ (white maize/sugar-extruded) as the least. Moisture content ranged from $6.65-7.15 \%$, $4.50-8.45 \%$ and $2.70-3.55 \%$ for the sugar baked granola, date baked granola and extruded granola, respectively with a significant difference between them $(\mathrm{p} \leq 0.05)$. The moisture content of sugar baked granola is slightly higher than the finding of Eke-Ejiofor et al [9] with values ranging $5.65-6.75 \%$. The date baked granola is less than the findings of Agbaje et al., [2] with value of $12.90-18.73 \%$ which was produced with puffed glutinous rice and dried Sunnah foods. The substitution of sugar with date in the samples showed lower moisture content when compared with those produced with sugar. This finding disagrees with the finding of Obiegbuna et al., [5] on the moisture content of granulated sugar and date fruit with the value of 3.11 and $6.56 \%$, respectively. Also, the moisture content of the extruded granola is very low due to the little amount of water used in conditioning the feed to about $21-22 \%$ moisture content. The low amount of all the granola samples indicates better shelf life as products with less than $12 \%$ moisture content have shown to store over a long period without deterioration in color, quality or taste.

Table 2. Sensory Evaluation Result of Extruded Granola Samples

\begin{tabular}{|c|c|c|c|c|c|}
\hline Samples & Color & Taste & Flavor & Texture & Overall acceptability \\
\hline I & $3.35^{\mathrm{c}}$ & $4.05^{\mathrm{a}}$ & $3.60^{\mathrm{a}}$ & $3.95^{\mathrm{a}}$ & $4.15^{\mathrm{a}}$ \\
\hline $\mathrm{J}$ & $3.90^{\mathrm{a}}$ & $3.90^{\mathrm{a}}$ & $3.90^{\mathrm{a}}$ & $3.90^{\mathrm{a}}$ & $3.90^{\mathrm{a}}$ \\
\hline K & $4.05^{\mathrm{a}}$ & $3.35^{\mathrm{b}}$ & $3.35^{\mathrm{b}}$ & $3.55^{\mathrm{a}}$ & $3.75^{\mathrm{a}}$ \\
\hline $\mathrm{L}$ & $3.60^{\mathrm{b}}$ & $3.00^{\mathrm{c}}$ & $3.00^{\mathrm{c}}$ & $3.00^{\mathrm{a}}$ & $3.00^{\mathrm{b}}$ \\
\hline
\end{tabular}

Means with the same superscript in the same column are not significantly different $(\mathrm{P}<0.05)$

Key: $\quad \mathbf{I}=$ yellow maize $/$ date extruded

$\mathbf{J}=$ white maize / sugar extruded

$\mathbf{K}=$ guinea corn /sugar extruded

$\mathbf{L}=$ millet / date extruded

Table 3. Chemical Composition (\%) Result of Granola Sample

\begin{tabular}{|c|c|c|c|c|c|c|c|c|c|}
\hline Sample & Moisture & Ash & Fat & Fiber & Protein & CHO & Sugar & $\operatorname{Starch}(g / 100 g)$ & Energy (kcal) \\
\hline $\mathbf{A}$ & $7.15^{b c} \pm 0.25$ & $1.07^{\mathrm{d}} \pm 0.21$ & $12.67^{\mathrm{ab}} \pm 0.0$ & $7.26^{j} \pm 0.00$ & $12.08^{\mathrm{fgh}} \pm 0.0$ & $56.4^{\mathrm{h}} \pm 30.0$ & & & $388.07^{\mathrm{g}} \pm 0.00$ \\
\hline B & $6.90^{\mathrm{bcd}} \pm 0.00$ & $1.76^{\mathrm{abc}} \pm 0.23$ & $10.36^{\mathrm{d}} \pm 0.13$ & $5.92^{\mathrm{k}} \pm 0.01$ & $14.08^{\mathrm{c}} \pm 0.02$ & $54.97^{\mathrm{k}} \pm 0.01$ & $13.28^{\mathrm{d}} \pm 0.00$ & $11.93^{\mathrm{def}} \pm 0.00$ & $369.44^{1} \pm 0.00$ \\
\hline $\mathrm{C}$ & $7.65^{\mathrm{ab}} \pm 0.65$ & $1.44^{\mathrm{bc}} \pm 0.35$ & $11.80^{\mathrm{b}} \pm 1.03$ & $8.14^{\mathrm{i}} \pm 0.04$ & $12.13^{\mathrm{efg}} \pm 0.01$ & $58.81^{\mathrm{d}} \pm 0.01$ & $12.49^{\mathrm{i}} \pm 0.04$ & $11.25^{\mathrm{i}} \pm 0.01$ & $389.96^{\mathrm{f}} \pm 0.00$ \\
\hline $\mathrm{D}$ & $6.65^{\text {cde }} \pm 0.25$ & $1.19^{\mathrm{bc}} \pm 0.22$ & $10.83^{c} \pm 0.32$ & $12.38^{\mathrm{c}} \pm 0.01$ & $11.7^{\mathrm{i}} \pm 0.00$ & $57.15^{\mathrm{e}} \pm 0.05$ & $14.12^{\mathrm{b}} \pm 0.00$ & $12.71^{\mathrm{b}} \pm 0.03$ & $373.07^{\mathrm{k}} \pm 0.00$ \\
\hline $\mathrm{E}$ & $6.10^{\mathrm{de}} \pm 0.40$ & $2.27^{\mathrm{a}} \pm 0.18$ & $12.23^{b} \pm 2.64$ & $9.80^{\mathrm{g}} \pm 0.00$ & $15.17^{\mathrm{b}} \pm 0.01$ & & & $11.36^{\mathrm{h}} \pm 0.00$ & $392.79^{\mathrm{e}} \pm 0.00$ \\
\hline $\mathrm{F}$ & $8.45^{\mathrm{a}} \pm 0.25$ & $1.93^{\mathrm{abc}} \pm 0.24$ & $13.78^{\mathrm{ab}} \pm 0.04$ & $11.8^{\mathrm{d}} \pm 0.00$ & $13.72^{\mathrm{d}} \pm 0.02$ & $56.19^{\mathrm{i}} \pm 0.01$ & $13.90^{\mathrm{f}} \pm 0.02$ & $12.51^{\mathrm{c}} \pm 0.02$ & $403.66^{\mathrm{d}} \pm 0.00$ \\
\hline G & $4.50^{\mathrm{f}} \pm 0.00$ & $1.53^{\mathrm{bc}} \pm 0.46$ & $16.36^{\mathrm{a}} \pm 1.06$ & $8.47^{\mathrm{h}} \pm 0.00$ & $12.32^{\mathrm{ef}} \pm 0.02$ & $56.83^{\mathrm{g}} \pm 0.00$ & $12.9^{\mathrm{ci}} \pm 30.00$ & $11.63^{\mathrm{g}} \pm 0.01$ & $423.84^{\mathrm{a}} \pm 0.00$ \\
\hline $\mathrm{H}$ & $5.10^{\mathrm{f}} \pm 0.30$ & $2.01^{\mathrm{ab}} \pm 0.69$ & $15.07^{\mathrm{ab}} \pm 0.29$ & $10.54^{\mathrm{e}} \pm 0.01$ & $16.66^{\mathrm{a}} \pm 0.01$ & $50.64^{1} \pm 0.00$ & $14.5^{\mathrm{a}} \pm 10.01$ & $13.06^{\mathrm{a}} \pm 0.01$ & $404.83^{\mathrm{c}} \pm 0.00$ \\
\hline I & $3.20^{\mathrm{g}} \pm 0.10$ & $1.71^{\mathrm{abc}} \pm 0.48$ & $11.42^{\mathrm{b}} \pm 0.42$ & $14.19^{\mathrm{a}} \pm 0.01$ & $12.45^{\mathrm{e}} \pm 0.00$ & $57.05^{\mathrm{f}} \pm 0.00$ & $13.18^{\mathrm{e}} \pm 0.01$ & $12.06^{\mathrm{e}} \pm 0.18$ & $380.78^{\mathrm{j}} \pm 0.00$ \\
\hline $\mathrm{J}$ & $2.70^{\mathrm{g}} \pm 0.00$ & $1.61^{\mathrm{abc}} \pm 0.38$ & $10.01^{\mathrm{e}} \pm 0.20$ & $12.74^{\mathrm{b}} \pm 0.01$ & $9.65^{j} \pm 0.35$ & $63.66^{\mathrm{a}} \pm 0.00$ & $12.59^{\mathrm{gh}} \pm 0.00$ & $12.59^{\text {bcd }} \pm 0.00$ & $383.88^{\mathrm{i}} \pm 0.00$ \\
\hline $\mathrm{K}$ & $2.85^{\mathrm{g}} \pm 0.15$ & $1.60^{\mathrm{abc}} \pm 0.36$ & $11.30^{b} \pm 1.20$ & $9.97^{\mathrm{f}} \pm 0.00$ & $11.62^{\mathrm{i}} \pm 0.00$ & $59.61^{\mathrm{c}} \pm 0.01$ & $12.0^{\mathrm{j}}+0.00$ & $12.04^{\mathrm{ef}} \pm 0.00$ & $386.62^{\mathrm{h}} \pm 0.00$ \\
\hline $\mathrm{L}$ & $3.55^{\mathrm{g}} \pm 0.05$ & $1.47^{\mathrm{bc}} \pm 0.61$ & $13.56^{\mathrm{ab}} \pm 3.10$ & $10.00^{\mathrm{f}} \pm 0.00$ & $11.92^{\mathrm{ghi}} \pm 0.02$ & $62.48^{\mathrm{b}} \pm 0.00$ & $12.6^{\mathrm{gh}}+0.01$ & $12.61^{\mathrm{bc}} \pm 0.01$ & $419.64 \pm^{\mathrm{b}} 0.00$ \\
\hline
\end{tabular}

Means with same superscript in the same column are not significantly different $(\mathrm{P}<0.05)$

Key: $\quad \mathrm{A}=$ yellow maize/sugar baked, $\mathrm{B}=$ white maize/sugar baked, $\mathrm{C}=$ Guinea corn/sugar baked, $\mathrm{D}=\mathrm{Millet} / \mathrm{sugar}$ baked,

$\mathrm{E}=$ Yellow maize / date baked, $\mathrm{F}=$ White maize $/$ date baked, $\mathrm{G}=$ Guinea corn $/$ date baked, $\mathrm{H}=\mathrm{Millet} / \mathrm{date}$ baked,

$\mathrm{I}=$ yellow maize/date extruded, $\mathrm{J}=$ white maize/sugar extruded, $\mathrm{K}=$ Guinea corn/sugar extruded, $\mathrm{L}=$ millet/ date extruded

M.C = Moisture content, $\mathbf{C H O}=$ Carbohydrate . 
Ash content ranged from $1.07-2.27 \%$ with sample A (yellow maize/sugar-baked) as the highest and sample E (yellow maize/date-baked) as the highest. Fat content ranged from $10.01-16.36 \%$ with sample $\mathrm{G}$ (millet/date-baked) as the highest and sample $\mathrm{J}$ (white maize / sugar-extruded) as the least. The ash content ranging from $1.07-1.76 \%$ for sugar baked granola samples (samples A -D) is higher than the finding of Eke -Ejiofor and Beleya [9]. The date baked granola had ash content ranging from $1.53-2.27 \%$ which agrees to the finding of Agbaje et al., [2] with puffed glutinous rice and dried sunnah foods. It also agrees with the ash content of date fruit pulp reported by Obiegbuna et al., [5]. The ash content of the extruded granola ranging from $1.47-1.71 \%$ is less than the findings of Sushil et al., (2016) on extruded snacks and the difference may be due to the different recipes used as well as the cereal which is the carbohydrate source in the production. This study showed that the incorporation of date increased the ash content of the granola with significant difference $(p \leq 0.05)$ between the samples.

Fat content of granola ranged from $10.36-12.67 \%$, $12.23-16.36 \%$ and $10.01-13.56 \%$ for the sugar baked, date baked and extruded granola, respectively with significant difference between the samples $(\mathrm{p} \leq 0.05)$. The sugar baked granola had fat content less than the findings of EkeEjiofor and Beleya [9] which ranged from 13.45-16.09\%, but higher than that reported by Agbaje et al., [2]. This difference may be traced to the vegetable oil, peanut and coconut used in this study. Furthermore, this study showed that the use of date increased the fat content of the granola which has shown to be high in unsaturated fat [5].

Crude fiber ranged from $5.92-14.19 \%$ with sample I (yellow maize /date-extruded) as the highest and sample B (white maize /sugar-baked) as the least. Crude fibre content ranging from $5.92-12.38 \%, 8.47-11.88 \%$ and $9.97-14.19 \%$ for the sugar baked, date baked and extruded granola, respectively, showed that the use of date increased the fibre content of the samples with the extruded products showing higher values when compared with the baked products. The extruded products values are higher than the findings of Mohammad et al [26] with $2.89 \%$ which was extruded with cereals and pulses. This difference may be due to the whole grain and coconut used in the present study as against the flour used in previous research. The samples differ significantly $(\mathrm{p} \leq 0.05)$.

Protein content ranged from $11.62-16.66 \%$ with sample $\mathrm{H}$ (millet/date-baked) as the highest and sample $\mathrm{K}$ (guinea corn /sugar-extruded) as the least. In agreement with the present results, Obilana and Taylor [27] reported that millets has been found to be of more nutritional value than most cereals because of their high level of proteins in terms of amino acids such as methionine, cystine and other vital amino acids necessary for human health. Protein content ranged from $11.75-14.08 \%, 12.32-16.66 \%$ and $9.65-12.45 \%$ for the sugar baked, date baked and extruded samples, respectively. The samples differ significantly $(\mathrm{p} \leq 0.05)$. The protein content of the sugar baked granola in the present study is higher than the findings of Eke -Ejiofor and Beleya [9] except for the oat based granola $(12.45 \%)$ that corresponds to the present study. The date baked samples are in agreement with the findings of Sushil et al., [1] with sample H (baked millet + date) as the highest. The protein content of the extruded samples is in agreement with the finding of Mohammad et al., [15] with values of $11.00-15.15 \%$. Sample I (extruded yellow maize) was the most preferred. There was significant difference between the samples. The use of date as sugar replacer increased the protein content of the granola samples with the exception of sample F showing a reverse trend. Also, extrusion process of granola showed a decrease in the protein content of the granola samples except sample $\mathrm{L}$ which showed a reverse trend when compared to the sugar baked samples. This decrease in the protein content of the granola samples may be attributed to the denaturation effect of heat on the samples.

Carbohydrate ranged from 54.97-63.66\% with sample J (white maize /sugar-extruded) as the highest and B (white maize /sugar-baked) as the least. Carbohydrate content ranged from $54.97-58.81 \%, 50.64-56.83 \%$ and 57.05 $63.66 \%$ for the sugar baked, date baked and extruded samples, respectively. The result showed a higher carbohydrate content in sugar baked than in date baked granola. This agrees with the finding of Obiegbua et al., [5] on the carbohydrate content of granulated sugar (95.88\%) being higher than that of date fruit $(79.44 \%)$. An increase in carbohydrate content was shown with the extruded samples when compared to the sugar baked regardless of date or sugar used. The samples showed a significant difference $(p \leq 0.05)$

Sugar content ranged from $12.04-14.51 \%$ with sample $\mathrm{H}$ (millet/date-baked) as the highest and sample $\mathrm{K}$ (guinea corn / sugar-extruded) as the least. Total sugar content ranged from $12.45-13.28 \%, 12.62-14.51 \%$ and $12.04-13.18 \%$ for the sugar baked, date baked and extruded granola, respectively. The samples showed a significant difference, while starch ranged from 11.20-13.06g/100g with sample A (yellow maize/sugar-baked) as the least and sample $\mathrm{H}$ (millet/date-baked) as the highest. Starch content ranged from $11.20-12.71 \mathrm{~g} / 100 \mathrm{~g}, 11.36-13.06 \mathrm{~g} / 100 \mathrm{~g}$ and $12.04-12.61 \mathrm{~g} / 100 \mathrm{~g}$ for the sugar baked, date baked and extruded granola, respectively. Date inclusion in the baked samples showed an increase in the dietary starch content. Dietary starch otherwise known as resistant starch in foods helps with appetite suppression and reduces risks associated with diabetes and colon cancer [28].

Energy content ranged from 369.44 - $419.64 \mathrm{kcal}$ with sample G (guinea corn/date-baked) as the least and sample $\mathrm{H}$ (millet/date-baked) as the highest. This is less than the finding of Eke -Ejiofor and Beleya [9] with $448 \mathrm{kcal}$. The energy content of the date baked is less than the findings of Agbaje et al., [2] with 379.80 kcal which may be a reflection of the cereal material used. The energy content increased with the addition of date in baked samples than the sugar baked samples as well as a higher energy value observed in extruded granola when compared with the findings of Mohammad et al., [15] with $347.80 \mathrm{kcal}$. There was significance difference between the samples $(\mathrm{p} \leq 0.05)$.

\subsection{Functional Analysis Result of Granola Samples}

Table 4 shows the functional properties of baked and extruded granola samples produced with sugar and date. Dispersibility ranged from $73.75-80.25 \%$ with sample I (extruded yellow maize) as the highest and sample $G$ and 
$\mathrm{H}$ (date baked guinea corn and millet, respectively) as the least. There was significant difference $(P \leq 0.05)$ between the samples. Dispersibility shows the ease of separation of sample mass which allows particles to sink below the surface and disperse rapidly in liquid [29]. Kulkarni et al., [21] reported that the higher the dispersibility of a starch based product, the better the starch reconstitutes in water.

Solubility ranged from $19.51-28.18 \%$ with samples A (sugar-baked yellow maize) as the least and J (white maize / sugar-extruded) as the highest. There was significant difference $(\mathrm{P} \leq 0.05)$ between the samples. Solubility shows the extent of Intermolecular cross bonding within the granules [30].

Swelling power ranged from $4.37-5.28 \mathrm{~g} / \mathrm{g}$ with samples K (guinea corn /sugar-extruded) as the highest and L (millet/date-extruded) as the least. Swelling power ranging from $4.37-5.28 \mathrm{~g} / \mathrm{g}$ agrees with the finding of Eke -Ejiofor et al., [9] who reported a value of 4.57- $5.89 \mathrm{~g} / \mathrm{g}$ in an earlier study of granola. Sample K (extruded guinea corn) was the highest. There was significant difference between the samples $(\mathrm{p} \leq 0.05)$.
Swelling capacity is a function of the product to rise when having interaction with water [9].

Water absorption capacity ranged from $0.97-1.95 \mathrm{~g} / \mathrm{g}$ with sample A (sugar baked yellow maize) as the least and sample $\mathrm{H}$ (date baked millet granola) as the highest. The study showed a significant difference $(\mathrm{p} \leq 0.05)$ between the samples. The date baked granola had higher water absorption than the sugar baked and extruded granola products. This may be due as a result of the high fiber content of date fruit. Water absorption helps in bulking and consistency of products and an increase in food systems enables end users to manipulate the functional properties of the dough in bakery products [9].

Bulk density ranged from $0.12-0.27 \mathrm{~g} / \mathrm{ml}$ with sample $\mathrm{K}$ (guinea corn /sugar-extruded) as the least and sample I (yellow maize /date-extruded) as the highest. This result agrees with the work of Mohammad et al., [15]. There was a significant difference $(\mathrm{p} \leq 0.05)$ between the samples. Bulk density helps in packaging and material handling since a high bulk density gives room for higher amount of material occupying a smaller volume [31].

Table 4. Functional Properties (\%) Result of Granola Samples

\begin{tabular}{|c|c|c|c|c|c|}
\hline Samples & Dispersibility (\%) & Solubility (\%) & Swelling Power(g/g) & Water Absorption (g/g) & Bulk Density $(\mathrm{g} / \mathrm{ml})$ \\
\hline A & $75.75^{\mathrm{d}} \pm 0.00$ & $19.51^{1} \pm 0.00$ & $4.43^{\mathrm{ab}} \pm 0.00$ & $0.97^{b} \pm 0.00$ & $0.21^{\mathrm{e}} \pm 0.00$ \\
\hline B & $75.25^{\mathrm{de}} \pm 0.25$ & $20.42^{\mathrm{k}} \pm 1.60$ & $4.70^{\mathrm{ab}} \pm 0.06$ & $1.77^{\mathrm{a}} \pm 0.51$ & $0.21^{\mathrm{e}} \pm 0.00$ \\
\hline $\mathrm{C}$ & $77.00^{\mathrm{c}} \pm 0.00$ & $25.16^{\mathrm{c}} \pm 2.41$ & $4.49^{\mathrm{ab}} \pm 0.16$ & $1.66^{\mathrm{ab}} \pm 0.59$ & $0.19^{\mathrm{f}} \pm 0.00$ \\
\hline $\mathrm{D}$ & $75.75^{d} \pm 0.25$ & $25.33^{\mathrm{b}} \pm 1.34$ & $4.61^{\mathrm{ab}} \pm 0.24$ & $1.75^{\mathrm{a}} \pm 0.55$ & $0.21^{\mathrm{e}} \pm 0.00$ \\
\hline $\mathrm{E}$ & $74.75^{\mathrm{e}} \pm 0.25$ & $24.72^{\mathrm{d}} \pm 0.43$ & $5.02^{\mathrm{ab}} \pm 0.25$ & $1.89^{\mathrm{a}} \pm 0.72$ & $0.18^{g_{ \pm}} 0.00$ \\
\hline $\mathrm{F}$ & $79.75^{\mathrm{abc}} \pm 0.25$ & $22.73^{\mathrm{h}} \pm 0.44$ & $4.91^{\mathrm{ab}} \pm 0.21$ & $1.90^{\mathrm{a}} \pm 0.63$ & $0.23^{\mathrm{d}} \pm 0.00$ \\
\hline G & $73.75^{\mathrm{f}} \pm 0.25$ & $24.43^{f} \pm 2.86$ & $4.75^{a b} \pm 0.37$ & $1.94^{\mathrm{a}} \pm 0,52$ & $0.22^{\mathrm{e}} \pm 0.00$ \\
\hline $\mathrm{H}$ & $73.75^{\mathrm{f}} \pm 0.25$ & $21.95^{\mathrm{j}_{ \pm}} 0.40$ & $4.59^{a b} \pm 0.06$ & $1.95^{\mathrm{a}} \pm 0.57$ & $0.26^{\mathrm{b}} \pm 0.02$ \\
\hline I & $80.25^{\mathrm{a}} \pm 0.25$ & $24.69^{\mathrm{e}} \pm 1.71$ & $4.47^{\mathrm{ab}} \pm 0.17$ & $1.65^{\mathrm{ab}} \pm 0.60$ & $0.27^{\mathrm{a}} \pm 0.02$ \\
\hline $\mathrm{J}$ & $80.00^{\mathrm{b}} \pm 0.00$ & $28.18^{\mathrm{a}} \pm 1.45$ & $4.69^{a b} \pm 0.15$ & $1.49^{\mathrm{ab}} \pm 0.58$ & $0.23^{\mathrm{d}} \pm 0.00$ \\
\hline $\mathrm{K}$ & $75.75^{\mathrm{d}} \pm 0.25$ & $22.31^{\mathrm{i}} \pm 1.38$ & $5.28^{\mathrm{a}} \pm 0.04$ & $1.70^{\mathrm{ab}} \pm 0.62$ & $0.12^{h^{h}} \pm 0.01$ \\
\hline $\mathrm{L}$ & $75.75^{\mathrm{d}} \pm 0.25$ & $24.10^{\mathrm{j}} \pm 1.09$ & $4.37^{b} \pm 0.83$ & $1.70^{\mathrm{ab}} \pm 0.69$ & $0.25^{\mathrm{c}} \pm 0.00$ \\
\hline
\end{tabular}

Means with the same superscript in the same column are not significantly different $(\mathrm{P}<0.05)$ Key:

$\mathrm{A}=$ yellow maize/sugar baked, $\mathrm{B}=$ white maize/sugar baked, $\mathrm{C}=$ Guinea corn/sugar baked,

$\mathrm{D}=$ Millet / sugar baked, $\mathrm{E}=$ Yellow maize / date baked, $\mathrm{F}=$ White maize / date baked,

$\mathrm{G}=$ Guinea corn / date baked, $\mathrm{H}=$ Millet / date baked, $\mathrm{I}=$ yellow maize/date extruded,

$\mathrm{J}=$ white maize/sugar extruded, $\mathrm{K}=$ Guinea corn/sugar extruded, $\mathrm{L}=$ millet/ date extruded.

Table 5. Mineral Composition (mg/100g) of Granola Samples

\begin{tabular}{|c|c|c|c|c|c|}
\hline Sample & Calcium (Ca) & Iron $(\mathbf{F e})$ & Sodium (Na) & Potassium (K) & Magnesium (Mg) \\
\hline A & $2,273^{\mathrm{a}} \pm 0.00$ & $7.79^{\mathrm{f}} \pm 0.00$ & $298.90^{\mathrm{e}} \pm 0.00$ & $553.00^{\mathrm{e}} \pm 0.00$ & $257.77^{\mathrm{e}} \pm 0.00$ \\
\hline $\mathrm{E}$ & $1462^{\mathrm{e}} \pm 0.00$ & $12.62^{\mathrm{d}} \pm 0.00$ & $538.73^{\mathrm{b}} \pm 0.00$ & $701.86^{\mathrm{b}} \pm 0.00$ & $306.12^{\mathrm{b}} \pm 0.00$ \\
\hline I & $1978^{b} \pm 0.00$ & $16.50^{c} \pm 0.00$ & $540.24^{\mathrm{a}} \pm 0.00$ & $740.29^{\mathrm{a}} \pm 0.00$ & $251.74^{\mathrm{f}} \pm 0.00$ \\
\hline $\mathrm{C}$ & $1528^{\mathrm{d}} \pm 0.00$ & $12.02^{\mathrm{d}} \pm 0.00$ & $298.98^{\mathrm{e}} \pm 0.00$ & $655.74^{\mathrm{c}} \pm 0.00$ & $308.52^{\mathrm{a}} \pm 0.00$ \\
\hline $\mathrm{G}$ & $1880^{c} \pm 0.00$ & $17.16^{\mathrm{b}} \pm 0.00$ & $392.44^{\mathrm{c}} \pm 0.00$ & $664.98^{\mathrm{d}} \pm 0.00$ & $296.46^{\mathrm{d}} \pm 0.00$ \\
\hline K & $505^{\mathrm{f}} \pm 0.00$ & $21.50^{\mathrm{a}} \pm 0.00$ & $329.92^{\mathrm{d}} \pm 0.00$ & $569.48^{\mathrm{f}} \pm 0.00$ & $301.09^{c} \pm 0.00$ \\
\hline
\end{tabular}

Means with the same superscript in the same are not significantly different $((\mathrm{P}<0.05$

Key : $\quad \mathbf{A}=$ Baked Yellow maize/sugar, $\mathbf{E}=$ Baked Yellow maize/date, $\mathbf{I}=$ Extruded Yellow maize/date, $\mathbf{C}=$ Baked Guinea corn $/$ sugar, $\mathbf{G}=$ Baked Guinea corn / date

$\mathbf{K}=$ Extruded Guinea corn/sugar. 


\subsection{Mineral Content (mg/100g) of Granola Samples}

Table 5 shows the total mineral composition of six granola samples produced from yellow maize, guinea corn, date or sugar with different processing methods. Calcium (Ca) content ranged from 505 - 2,273 mg/100g with sample K (extruded guinea corn) as the least and sample A (sugar baked yellow maize) as the highest. There was significant difference $(\mathrm{p} \leq 0.05)$ between the samples. This difference in value may be due to the different cereals and processing methods used in the production. Calcium plays a role in most body metabolic processes and provides rigidity to the skeleton [9]. Maize contain high amount of phosphorus, potassium and magnesium but low in calcium, sodium, zinc etc [32]. This finding corresponds to the work of Matilda et al. [33] who proposed that cereals are poor in zinc and calcium. Processing and milling of maize can reduce or remove most of these minerals through the removal of bran.

Iron content $(\mathrm{Fe})$ of samples ranged from $7.79-21.50$ $\mathrm{mg} / 100 \mathrm{~g}$ with sample A (Sugar baked yellow maize) as the least and sample $\mathrm{K}$ (extruded guinea corn) as the highest. The extruded samples (I and K) had higher iron content than the baked samples. The samples differed significantly $(p \leq 0.05)$. Iron is important in haemoglobin formation, oxygen and electron transport in the human body (Kalagbor and Diri, 2014)[34]. The Iron content in this study is less than the maximum limit of iron concentration in food given by $\mathrm{FAO} / \mathrm{WHO}$ [35] which is $42.5 \mathrm{mg} / 100 \mathrm{~g}$. Also the iron in this study corresponds to the Recommended Daily Allowance (RDA) of iron $15 \mathrm{mg} /$ day for females $14-18$ years and $11 \mathrm{mg} /$ day for males 14-18 years [36].

Sodium (Na) content ranged from 298.90 - 540.24 $\mathrm{mg} / 100 \mathrm{~g}$ samples A (sugar baked yellow maize) as the least and sample I (extruded yellow maize) as the highest with significant difference between the samples $(\mathrm{p} \leq 0.05)$. Sodium is the major cation in extracellular fluid in the body and necessary for maintenance of plasma volume, acid-base balance, normal cell function and transmission of nerve impulse [9].

Potassium ranged from $416-702 \mathrm{mg} / 100 \mathrm{~g}$ with sample E (yellow maize / date-baked) as the highest and sample K (guinea corn / sugar-extruded) as the least. Potassium (K) content ranged from 553.00 - $740.29 \mathrm{mg} / 100 \mathrm{~g}$ with sample I (extruded yellow maize) as the highest. The was significant difference $(\mathrm{p} \leq 0.05)$ amongst the samples. Potassium is a major nutrient for the maintenance of total body fluid volume, acid and electrolyte balance [36].
Magnesium (Mg) content ranged from 251.74 - 308.52 $\mathrm{mg} / 100 \mathrm{~g}$ with sample I (extruded yellow maize) as the least and sample C (Sugar baked guinea corn) as the highest. There was significant difference $(\mathrm{p} \leq 0.05)$ between the samples.

\subsection{Mineral Soluble Fraction (Bioavailability) of Granola Samples}

Table 7 shows the percentage soluble fraction of granola. The bioavailability of minerals refers to the proportion of mineral intake capable of being absorbed through the intestine and made available either for metabolic use or storage [11]. Percentage soluble fraction of calcium ranged from $4.70-52.76 \mathrm{mg} / 100 \mathrm{~g}$ with sample A (yellow maize /sugar-baked) as the least and sample $\mathrm{K}$ (guinea corn/ sugar-extruded) as the highest. There was significant difference $(\mathrm{p} \leq 0.05)$ between the samples.

The percentage soluble proportion of iron ranged from 67.63 - 93.09mg/100g with sample C (guinea corn / sugar-baked) as the least and sample I (yellow maize / date-extruded) as the highest. These values represent the proportion of iron released after enzymatic digestion of the samples. An increase in Iron was shown in the extruded products with no significant difference $(\mathrm{p} \geq 0.05)$ between the samples.

The soluble sodium fraction available for absorption ranged from $46.85-91.29 \mathrm{mg} / 100 \mathrm{~g}$ with sample I (yellow maize/ date-extruded) as the least and sample $\mathrm{C}$ (guinea corn / sugar-baked) as the highest. There was significant difference $(p \leq 0.05)$ between the samples. Sugar baked granola (A and $\mathrm{C}$ ) showed to have a higher sodium content than the date baked samples ( $E$ and $G$ ) with the extruded samples (I and K) having the least.

Potassium soluble fraction ranged from $73.02-90.25$ $\mathrm{mg} / 100 \mathrm{~g}$. There was significant difference between the samples $(\mathrm{p} \leq 0.05)$ with sample $\mathrm{K}$ (guinea corn / sugarextruded) as the least and sample I (extruded yellow maize) as the highest. The study showed a reduction in potassium content with date baked granola (E and $\mathrm{G}$ ) when compared to the sugar baked samples (A and C).

The percentage soluble fraction and bioavailable magnesium ranged from 10.39 - $30.97 \mathrm{mg} / 100 \mathrm{~g}$ with sample K (guinea corn / sugar-extruded) as the least and sample G (guinea corn / date-baked) as the highest. The study showed date baked granola ( $\mathrm{E}$ and $\mathrm{G}$ ) to have higher magnesium content than the others. The samples were statistically different from each other in term of the mineral content.

Table 6. Digested Fraction (Mineral) (mg/100g) Result after Invitro Digestion

\begin{tabular}{|c|c|c|c|c|c|}
\hline Sample & Calcium & Iron & Sodium & Potassium & Magnesium \\
\hline A & $106.94^{\mathrm{f}} \pm 0.00$ & $5.28^{\mathrm{f}} \pm 0.00$ & $261.13^{\mathrm{d}} \pm 0.00$ & $481.38^{\mathrm{c}} \pm 0.00$ & $30.85^{\mathrm{f}} \pm 0.00$ \\
\hline $\mathrm{E}$ & $284.78^{\mathrm{a}} \pm 0.00$ & $10.53^{\mathrm{d}} \pm 0.00$ & $376.75^{\mathrm{a}} \pm 0.00$ & $594.88^{c} \pm 0.00$ & $49.11^{\mathrm{c}} \pm 0.00$ \\
\hline I & $274.90^{\mathrm{b}} \pm 0.00$ & $15.36^{\mathrm{a}} \pm 0.00$ & $253.12^{\mathrm{e}} \pm 0.00$ & $668.13^{\mathrm{a}} \pm 0.00$ & $30.98^{\mathrm{e}} \pm 0.00$ \\
\hline $\mathrm{C}$ & $269.38^{\mathrm{c}} \pm 0.00$ & $8.13^{\mathrm{e}} \pm 0.00$ & $272.95^{\mathrm{c}} \pm 0.00$ & $577.96^{\mathrm{d}} \pm 0.00$ & $52.90^{\mathrm{b}} \pm 0.00$ \\
\hline G & $229.64^{\mathrm{e}} \pm 0.00$ & $12.51^{\mathrm{c}} \pm 0.00$ & $287.98^{\mathrm{b}} \pm 0.00$ & $507.51^{\mathrm{b}} \pm 0.00$ & $91.84^{\mathrm{a}} \pm 0.00$ \\
\hline $\mathrm{K}$ & $267.00^{\mathrm{d}} \pm 0.00$ & $15.11^{\mathrm{b}} \pm 0.00$ & $232.61^{\mathrm{f}} \pm 0.00$ & $415.88^{\mathrm{f}} \pm 0.00$ & $31.40^{\mathrm{d}} \pm 0.00$ \\
\hline
\end{tabular}

Means with the same superscript in the same column are not significantly different.

Key : $\quad \mathbf{A}=$ Baked Yellow maize /sugar, $\mathbf{E}=$ Baked Yellow maize $/$ date, $\mathbf{I}=$ Extruded Yellow maize/date

$\mathbf{C}=$ Baked Guinea corn /sugar, $\mathrm{G}=$ Baked Guinea corn /date, $\mathbf{K}=$ Extruded Guinea corn/ sugar. 
Table 7. \% Soluble Fractions (Mineral) Result of Granola

\begin{tabular}{|c|c|c|c|c|c|}
\hline Sample & Calcium & Iron & Sodium & Potassium & Magnesium \\
\hline A & $4.70^{\mathrm{f}} \pm 0.00$ & $3.28^{\mathrm{f}} \pm 0.00$ & $87.36^{\mathrm{b}} \pm 0.00$ & $87.04^{\mathrm{c}} \pm 0.00$ & $11.96^{\mathrm{e}} \pm 0.00$ \\
\hline $\mathrm{E}$ & $19.47 \pm 0.00$ & $5.53^{\mathrm{d}} \pm 0.00$ & $69.93^{\mathrm{e}} \pm 0.00$ & $84.75^{\mathrm{d}} \pm 0.00$ & $16.04^{\mathrm{c}} \pm 0.00$ \\
\hline I & $13.8^{\mathrm{d}} \pm 0.00$ & $6.34^{\mathrm{c}} \pm 0.00$ & $46.85^{\mathrm{f}} \pm 0.00$ & $90.25^{\mathrm{a}} \pm 0.00$ & $12.30^{\mathrm{d}} \pm 0.00$ \\
\hline $\mathrm{C}$ & $17.62^{\mathrm{c}} \pm 0.00$ & $4.13^{\mathrm{e}} \pm 0.00$ & $91.29^{\mathrm{a}} \pm 0.00$ & $88.13^{\mathrm{b}} \pm 0.00$ & $17.14^{\mathrm{b}} \pm 0.00$ \\
\hline $\mathrm{G}$ & $12.21^{\mathrm{e}} \pm 0.00$ & $7.51^{\mathrm{b}} \pm 0.00$ & $73.38^{\mathrm{c}} \pm 0.00$ & $76.31^{\mathrm{e}} \pm 0.00$ & $30.97^{\mathrm{a}} \pm 0.00$ \\
\hline K & $52.76^{\mathrm{a}} \pm 0.00$ & $8.11^{\mathrm{a}} \pm 0.00$ & $70.50^{\mathrm{d}} \pm 0.00$ & $73.02^{\mathrm{f}} \pm 0.00$ & $10.39^{f} \pm 0.00$ \\
\hline
\end{tabular}

Means with the same superscript in the same column are not significantly different

Key : $\quad \mathbf{A}=$ Baked Yellow maize /sugar, $\mathbf{E}=$ Baked Yellow maize $/$ date, $\mathbf{I}=$ Extruded Yellow maize/ date

$\mathbf{C}=$ Baked Guinea corn / sugar, $\mathbf{G}=$ Baked Guinea corn / date, $\mathbf{K}=$ Extruded Guinea corn/sugar

\section{Conclusion}

Result from the study has shown that granola produced with different cereals is of accepted quality in sensory and nutritional evaluation. The study showed an increase in the amount of fat, protein, ash, crude fibre and energy content with a decrease in carbohydrate content in the samples produced with date when compared to those produced with sugar with no sensory differences. The increased fiber content in the date products would be of important health benefit in reducing cholesterol and cardiovascular ailments as well as inhibiting the actions of some food components such as phytic acid which reduces the bioavailability of some minerals during absorption. Furthermore, the low carbohydrate content in date is beneficial for weight loss. The use of date as sugar replacer has also shown an increase in bioavailability of minerals such as magnesium and iron but not all minerals detected in the products were bioavailable when digested enzymatically into soluble forms. This could be due to the presence of minerals having same charges, phytic acid, and type of processing method used and the absence of some vitamins that helps in mineral absorption. Extrusion processing method improved the crude fibre and carbohydrate content of the products with little or no sensory changes when compared to the conventional baking method.

\section{References}

[1] Sushil Kumar, Rajbala Grewal and Varsha Rani (2016). Standardization and Quality Evaluation of Ready To Eat Extruded Snacks developed using Maize-Oat blends and Processed Cowpea. International Journal of Food and Nutritional Sciences, 5(4): 2320-7876.

[2] Agbaje, R., Hassan, C. Z., Norlelawati, A., Abdul Rahman, A. and Huda-Faujan, N. (2016). Development and physico-chemical analysis of granola formulated with puffed glutinous rice and selected dried Sunnah foods. International Food Research Journal 23(2): 498-506.

[3] Eke-Ejiofor, J and Beleya, E.A. (2016). The composition and mineral content of Granola (Breakfast Cereal), produced from different locally available Cereal grains European Journal of Food Science and Technology. 4(5): 18-26.

[4] Anon (2010). Natural sugar substitute: 10 healthier alternatives to refined sugar. American Diabetes. Accessed May 2012.

[5] Obiegbuna J. E., P. I. Akubor, C. N. Ishiwu and J Ndife (2013). Effect of substituting sugar with date palm pulp meal on the physicochemical, organoleptic and storage properties of bread. African Journal of Food Science, 7(6):113-119.
[6] Akubor PI, Yusuf D (2007). Effect of incorporation of date palm syrup on the sensory and physical properties of wheat flour biscuit. Journal of Applied Science Environment 1:25-28.

[7] Ranilla LG, Kwon YI, Genovese MI, Lajolo FM, Shetty K. (2008). Antidiabetes Seow C.C; Gwee C.N. (1997) Coconut milk: chemistry and technology. International Journal of Food Science and Technology; 32: 189-201.

[8] Al-Kuran O, Al-Mehaisen L, Bawadi H, Beitawi S, Amarin Z (2011). The effect of late pregnancy consumption of date fruit on labourn and delivery. Journal of Obstetrics Gynaecology 31: 29-31.

[9] Eke-Ejiofor, J. Beleya E. A. and Gbarasosgo M.N. (2016). Preparation and Evaluation of Granola-a breakfast cereal, substituted with maize (Zea may) and coconut (Cocos nucifera) blend. International Journal of Nutrition and Food Science. 5(1): 47-52.

[10] https://en .m Wikipedia.Org $\geqslant$ Niki $\geqslant$ Granola.

[11] Lowe, J.A and J. Wiseman (1998). A Comparison of the bioavailability of three dietary Zinc sources using four different physiologic Parametres in dogs. Journal of Nutrition. 128: 2809-2811.

[12] Elless, M. P., Blaylock,M. J., Huang, J. W., \& Gussman, C.D. (2000). Plants as a natural source of concentrated mineral nutritional supplements. Food chemistry, 71: 181-188.

[13] David B. Kiin-Kabari, Sunday Y. Giami and Ndokiari(2015). Bioavailability of minerals nutrients in Plantain Based Products Enriched with Bambara Groundnut Protein Concentrate. Journal of Food Research; 4(4): 74-79.

[14] Charunuch, C., Limsangouan, N., Prasert, W. and Wongkrajang, K (2014). Optimization of extrusion conditions for ready-to-eat breakfast cereal enhanced with defatted rice bran. International Food Research Journal 21(2): 713-722

[15] Muhammad H. Sarwar, Muhammad F. Sarwar, Muhammad Sarwar, Niaz A. Qadri and Safia Moghal (2013). The importance of cereals (Poaceae: gramineae) nutrition in human health: A review. Academic journals, 4(3): 32-35.

[16] Larmond, E., (1977). Laboratory methods for sensory Evaluation of food, Canada Department of Agriculture.

[17] AOAC. (2012). Official methods of Analysis, Washington D.C, USA. Association of Official Analytical Chemists.

[18] Mahgoub, S.E.O. (1999). Production and Evaluation of hydrolysate from an oil sedd flour mixture. Food weaning foods based on sorghum and legumes"' Chem, 106:1166-1174. Plants Foods Human Nutrition 54:29-42

[19] Prapasri Puwastien, Tee E Siong,Julia Kantasubrata, Graham Craven Rafael Ryan Feliciano, Kunchit Judprasong (2011).Prime corn and wheat starches with and without native lipids". Cereal chemistry 65: 474-475.

[20] Narayana, K and Narasinga, Rao M. S. (1984). Effect of partial proteolysis on the functional properties of winged pea (Psophocapus tetragonolobus) flour. Journal of Food Science,49: 944-947.

[21] Kulkarni, k. D, kulkarni, D. N and Ingle, U. M. (1991). "Sorghum malt-based weaning formulation, preparation, functional properties and nutritive Values". Food and nutrition bulletin 13(4): 322-327.

[22] Takashi, S. and Sieb, P. A. (1988). Paste and gel properties of prime corn and wheat starches with and without native lipids". Cereal chemistry 65:474-475. 
[23] Sosulski, F. N. (1962): "The centrifugal method for determining flour absorptivity chemistry 39: 344-346. State University Ames, Iowa. Starch and modified starch. Starch 41(3): 88-91.

[24] Ikeda, S. (1990). Dietary zinc and zinc components of various foods subjected to in-vitro enzyme. Journal of the Science of Food and Agriculture, 53: 229-234.

[25] Peter G. Williams (2010). The benefits of Breakfast Cereals Consumption: A systematic Review of the evidence base. Advances in Nutrition, 5 (5): 636-673.

[26] Mohammad R. S, Kavita Waghray, Fahimeh Khoushabi (2014). Formulation, Preparation and Evaluation of Low-Cost Extrude Products Based on Cereals and Pulses. Food and Nutrition Sciences, 5: 1333-1340.

[27] Obilana, A.B., Taylor, J.R.N. (2002). Status and development needs of processing and utilization technologies for Sorghum and Millets: Experiences from Southern Africa and Implications for West and Central Africa (WCA). Presented to the CFC expert meeting to identify and prioritize research and development needs activities for WCA, Bamako, Mali.23-26 April. Pakistan. Pakistan Journal of Botany, 43(1): 357-363.

[28] David Mills (2017). Starch in Potatoes. Bananas, Breads provides Health Benefits. Healthline News.www.healthline.com.

[29] Tizazu H., Emire S.A (2010). "Chemical composition, physicochemical and functional properties of Lupin (Lupinusalbus) seed grown in Ethiopia". African Journal of Food, Agriculture, Nutrition and Development. 10(8): 3029-3046.

[30] Hari, P. K, Gargs, S; Garys, S. K (1989). Gelatinization of starch and modified starch. Starch 41(3): 88-91.

[31] Karma D, Noel D, DilipK (1981). Food and Nutrition Bulletin United Nation University. 17(2).

[32] Enyisi I.S., Umoh V.J., Whong C.M.Z., Abdullahi I.O., Alabi O. (2014). Chemical and nutritional value of maize and maize products obtained from selected markets in Kaduna State, Nigeria. African Journal of Food Science, 5(4):100-104.

[33] Matilda Asiedu, Rune Nilsen. Oyvind Lie, Einar L (1993). Effect of processing (Sprouting and or Fermentation) on Sorghum and Maize.1: Proximate Composition, Minerals and Fatty acids. Food Chemistry. 46:351-353.

[34] Kalagbor. I and Diri E. (2014). Evaluation of heavy metals in Orange, pineapple, avocado pear and pawpaw from a farm in Kaani, Bori. Rivers State Nigeria. International Research Journal of Public Environment Health 1(4):87-94.

[35] FAO/WHO (2001). Evaluation of Allergenicity of Genetically Modified Foods. Food, Agriculture, Nutrition and Development. 10(8):3029-3046.

[36] Federal Studies (2002). Family Economics and Nutrition Review, 41(2): 90.

[37] Yung, D.B (2001). Role of potassium in preventive cardiovascular medicine. Boston, Kluwer Academic Publishers. 